\title{
Observations of late-winter marine microbial activity in an ice-covered fjord, west Greenland
}

\author{
David Chandler $^{1}$ and Shona Mackie ${ }^{2,3}$ \\ ${ }^{1}$ School of Geographical Sciences, University of Bristol, Bristol, UK \\ ${ }^{2}$ School of Earth Sciences, University of Bristol, Bristol, UK \\ ${ }^{3}$ Department of Physics, University of Otago, Dunedin, New Zealand \\ Correspondence: David Chandler (davemchandler@gmail.com)
}

Received: 29 September 2019 - Discussion started: 7 November 2019

Revised: 17 February 2020 - Accepted: 25 March 2020 - Published: 23 April 2020

\begin{abstract}
Direct observations of marine microbial metabolism are sparse in the Arctic, particularly under sea ice during winter. This paper presents the first observations of Arctic winter microbial activity under sea ice in a west Greenland fjord (Lillefjord, $\sim 70^{\circ} \mathrm{N}$ ). Here, measured changes in dissolved oxygen (DO) content in light and dark in situ incubations were used to calculate net community productivity, respiration and photosynthesis rates. Data were collected at two fully ice covered sites during February 2013, shortly after the end of the polar night. Averaged over the full study period, dark incubations showed statistically significant decreases in DO of $-0.36 \pm 0.24$ (near shore) and $-0.09 \pm 0.07 \mathrm{~g} \mathrm{O}_{2} \mathrm{~m}^{-3} \mathrm{~d}^{-1}$ (fjord centre), indicating respiration rates that were 2-20 times greater than rates previously reported under sea ice in the Arctic. Meanwhile, a lack of significant evidence for photosynthesis suggests that the rate of photosynthesis - if it was occurring - was much lower than that of respiration. The data also show no significant evidence of a temporal trend in metabolism rates over the study period; however, ambient seawater DO increased significantly at the fjord centre $\left(0.023 \pm 0.013 \mathrm{~g} \mathrm{O}_{2} \mathrm{~m}^{-3} \mathrm{~d}^{-1}\right)$, possibly attributable to processes not occurring in the incubations (such as sea ice algal photosynthesis). These data may improve our understanding of microbial activity in the fjord during winter, and its contribution to Arctic ecosystems under present and future conditions. The data are archived at PANGAEA (https://doi.org/10.1594/PANGAEA.906332, Chandler and Mackie, 2019; https://doi.org/10.1594/PANGAEA.912677, Chandler and Mackie, 2020).
\end{abstract}

\section{Introduction}

There is increasing evidence for rapid climate change in the Arctic, with wide-reaching impacts in both terrestrial and marine environments (Wassmann et al., 2011; McMeans et al., 2013; Post et al., 2013; Comiso and Hall, 2014). The observed reduction in sea ice cover (duration, extent and/or thickness), and the corresponding increase in solar illumination in the upper layers of the Arctic Ocean, is of particular interest. While estimates of marine net primary productivity (NPP) based on satellite retrievals of chlorophyll $a$ have shown a link between reductions in sea ice cover and increases in NPP across much of the Arctic during 1998-2009, details of the processes associated with this change and its effects on higher levels of the food chain remain uncertain
(Hansen et al., 2003; Arrigo et al., 2008; Brown and Arrigo, 2012; Vancoppenolle et al., 2013).

The logistical challenges associated with making direct observations of Arctic marine microbial metabolism mean that very few field data are available with which to assess metabolism magnitudes and controlling factors (Matrai et al., 2013; Vaquer-Sunyer et al., 2013). Satellite retrievals of chlorophyll $a$ can provide excellent temporal and spatial coverage for monitoring NPP but have significant limitations. The data processing algorithms depend on multiple assumptions that may not be justified or appropriate in all cases ( $\mathrm{Ar}-$ rigo et al., 2008); for example there may not be a direct relationship between retrieved chlorophyll $a$ concentration and NPP (Flynn et al., 2013); data are unavailable for ocean wa- 
ter under sea ice and for sea ice itself, where productivity can be significant (Gosselin et al., 1997). Furthermore, the spatial resolution is generally too coarse to resolve smaller-scale features such as fjords, where the combination of nutrient inputs and buoyant mixing driven by subglacial meltwater discharge from marine-terminating glaciers can stimulate particularly high levels of productivity (Meire et al., 2017). Field observations of biological processes are therefore extremely valuable, both for improving and validating the parameterisations used in satellite retrieval algorithms and for providing information that cannot be measured remotely (e.g. in regions too small to be resolved by current remote sensing methods; or where observations of the individual components of microbial metabolism, and/or the variability of these with depth, are required).

Two approaches are generally followed for quantifying microbial metabolism: first, measuring the dissolved oxygen (DO) content of seawater in situ (Pomeroy, 1997; Rysgaard et al., 2001; Sherr and Sherr, 2003); or second, measuring changes in the concentration of chemical tracers in closed incubation experiments. The former method enables observations at high spatial and/or temporal resolution, but their interpretation is often challenging because the system is open: changes in oxygen concentration due to biological activity must be separated from those of physical processes such as mixing and air-water gas exchange. Monitoring ambient DO in this way only quantifies net community productivity (NCP). In the latter technique, changes in DO or radioisotope concentrations can be used to infer rates of biological processes (Smith, 1994, 1995; Gosselin et al., 1997; Rysgaard et al., 1999, 2001; Hill and Cota, 2005; Regaudie-de-Gioux and Duarte, 2010; Vaquer-Sunyer et al., 2013). This requires samples to be collected and incubated, potentially involving complex analytical procedures, and while in situ incubations are unlikely to fully replicate natural conditions, they allow for more controlled conditions. Comparison of simultaneous incubations of samples exposed to light and samples kept in the dark yields estimates of community respiration (CR, measured in the dark samples) and gross primary productivity (GPP, interpreted as the difference between the light and dark samples) in addition to NCP (light samples). Ideally, the two approaches are used in tandem (Sherr and Sherr, 2003; Cottrell et al., 2006). A recent approach combined in situ chlorophyll $a$ and irradiance observations with a numerical model to estimate NPP under pack ice (Assmy et al., 2017); while less direct than ambient DO measurements or incubations, this method can yield good spatial coverage, is not affected by oxygen exchange with the atmosphere, and provides detailed in situ observations that will help address the limitations of remotely sensed chlorophyll $a$ observations noted above.

Observations based on the above field methods have shown that several physical factors, notably dissolved nutrients and irradiance, as well as biological factors such as species composition and abundance, are each likely to play important roles in different environments and seasons, leading to a diverse range of measured metabolism rates (see Table 1 in this paper and Table 3 in Vaquer-Sunyer et al., 2013). The contribution of sea ice algae to the Arctic Ocean's annual primary production has also been observed to vary widely, for example ranging from $2 \%-57 \%$ (mean $17 \%$ ) in summer 1994 (Gosselin et al., 1997) to less than 1\% in Young Sound (NE Greenland) in summer 2000 (Rysgaard et al., 2001). The different methods and sampling strategies that are implemented by different teams make like-for-like comparison of observational data difficult. Despite both this and the high variability of the measured processes, some patterns have emerged. Notably, so-called blooms have been observed at, or shortly after, the break-up of the sea ice in summer, when microbial populations, chlorophyll $a$ concentrations and microbial metabolism (both GPP and CR) in the surface layers are seen to increase rapidly (Sherr et al., 2003; Belzille et al., 2008; Mikkelsen et al., 2008; Terrado et al., 2008; VaquerSunyer et al., 2013; Assmy et al., 2017).

While most measurements of metabolism have been carried out in ice-free summer conditions, there is evidence that microbial populations persist in both the sea ice and surface waters throughout the polar night (Berge et al., 2015; Vader et al., 2015) and can respond within a few days to increases in illumination (Zhang et al., 1998). Metabolism measurements in the water column under continuous sea ice, of which there are very few (Table 1), have detected community respiration during the polar night (Sherr and Sherr, 2003) but have yielded mixed results (positive, negative and insignificant NCP) during spring and summer (Gosselin et al., 1997; Cottrell et al., 2006, Seuthe et al., 2011; Vacquer-Sunyer et al., 2013). In Franklin Bay $\left(70^{\circ} \mathrm{N}\right)$, chlorophyll $a$ concentrations in sea ice algae and in the upper $11 \mathrm{~m}$ of the water column started to increase in mid-February, despite the persistence of continuous sea ice cover up to $2 \mathrm{~m}$ thick (Belzille et al., 2008), demonstrating how increasing activity by primary producers sometimes begins even under thick ice as daylight returns, well before ice break-up.

Models have predicted a strong ecological response to changing sea ice conditions along Greenland's west coast (Hansen et al., 2003), yet there are very few direct observations from the fjords that dominate Greenland's coastline (Rysgaard et al., 1999, 2001; Mikkelsen et al., 2008; Matrai et al., 2013). Although only accounting for a small fraction of the total sea surface area in the Arctic, fjord waters have the potential to make a disproportionately strong contribution to Arctic marine productivity. This is partly due to the extensive area of shallow water along the long fjord coastlines, where benthic production can be important (Glud et al., 2002; Attard et al., 2014), and partly to the large nutrient fluxes transported to the fjords in meltwater runoff from the Greenland Ice Sheet (Hawkings et al., 2014; Lawson et al., 2014; Meire et al., 2017).

There is a need for more observations of microbial metabolism in Greenland's fjords and under sea ice. Such 
Table 1. Measurements of microbial metabolism under Arctic sea ice. Net community production (NCP) and gross primary production (GPP) are positive if oxygen is being released. Community respiration (CR) is positive if oxygen is being consumed.

\begin{tabular}{|c|c|c|c|c|c|c|c|c|}
\hline & & & & & $\mathrm{NCP}$ & GPP & CR & \\
\hline Location & Depth (m) & Ice cover & Method & Dates & $\left(\mathrm{g} \mathrm{O}_{2} \mathrm{~m}^{-3} \mathrm{~d}^{-1}\right)$ & $\left(\mathrm{g} \mathrm{O}_{2} \mathrm{~m}^{-3} \mathrm{~d}^{-1}\right)$ & $\left(\mathrm{g} \mathrm{O}_{2} \mathrm{~m}^{-3} \mathrm{~d}^{-1}\right)$ & Source \\
\hline $\begin{array}{l}\text { Arctic Ocean } 75-90^{\circ} \mathrm{N} \\
\text { Chukchi Sea to North Pole }\end{array}$ & $0-60^{\mathrm{a}}$ & $>80 \%$ & $\begin{array}{l}\text { Inc }\left({ }^{14} \mathrm{C}\right), 12 \mathrm{~h} \text {, } \\
\text { artificial light }\end{array}$ & Jul-Aug 1994 & NR & $0.0004-0.0025^{\mathrm{b}}$ & NR & G97 \\
\hline $\begin{array}{l}\text { Young Sound, E Greenland } \\
74^{\circ} \mathrm{N} \sim 800 \mathrm{~m} \text { from } \\
\text { coast, in fjord } \\
\text { Ice thickness decreasing } \\
\text { from } \sim 2 \mathrm{~m}\end{array}$ & $0-35$ & $100 \%$ & $\begin{array}{l}\text { Inc }\left({ }^{14} \mathrm{C}\right), 2 \mathrm{~h} \text {, } \\
\text { artificial light }\end{array}$ & Jun 1996 & NR & $<0.005$ & NR & R99 \\
\hline \multirow[t]{4}{*}{ Central Arctic Ocean } & $0-50$ & $100 \%$ & Ambient DO & $\begin{array}{l}\text { Nov-May } \\
1997-1998\end{array}$ & -0.0025 & & & S03 \\
\hline & & & Inc (DO), & $\begin{array}{l}\text { Autumn-winter } \\
1997\end{array}$ & NM & NM & $0.019 \pm 0.014$ & \\
\hline & & & dark, $72 \mathrm{~h}$ & $\begin{array}{l}\text { Midwinter } \\
1997-1998\end{array}$ & NM & NM & & \\
\hline & & & & $\begin{array}{l}\text { Spring-summer } \\
1998\end{array}$ & NM & NM & $0.027 \pm 0.019$ & \\
\hline Chukchi Sea & $0-\sim 90$ & $>80 \%$ & $\begin{array}{l}\text { Inc }\left({ }^{14} \mathrm{C}\right) \\
\text { artificial light }\end{array}$ & Spring 2002 & $<0.003$ & NM & NM & H05 \\
\hline \multirow[t]{4}{*}{ Chukchi Sea } & & $100 \%$ & Inc $\left(\mathrm{DO} \&{ }^{14} \mathrm{C}\right)$ & May-Jun 2004 & & & & $\mathrm{C} 06^{\mathrm{b}}$ \\
\hline & Surface & & & & $+0.07 \pm 0.12$ & NM & $0.17 \pm 0.32$ & \\
\hline & $15 \%$ light & & & & $+0.22 \pm 0.11$ & NM & $0.06 \pm 0.01$ & \\
\hline & $1 \%$ light & & & & $+0.08 \pm 0.13$ & NM & $0.08 \pm 0.01$ & \\
\hline \multirow{3}{*}{$\begin{array}{l}\text { Kangerluarsunnguaq, } \\
\mathrm{W} \text { Greenland, } 64^{\circ} \mathrm{N} ; \\
\text { fjord } \sim 100 \mathrm{~m} \text { deep } \\
\text { Ice increasing } 0-50 \mathrm{~cm} \\
\text { thickness } \\
\text { Ice } \sim 60 \mathrm{~cm} \text { thickness }\end{array}$} & $0-50$ & & $\begin{array}{l}\text { Inc }\left({ }^{14} \mathrm{C}\right), 2 \mathrm{~h}, \\
\text { artificial light, } 4{ }^{\circ} \mathrm{C}\end{array}$ & & & & & M08 \\
\hline & & $100 \%$ & & $\begin{array}{l}\text { Dec-Mar } \\
\text { 2006-2007 }\end{array}$ & $<0.001$ & NM & NM & \\
\hline & & $100 \%$ & & Apr 2007 & +0.001 & NM & NM & \\
\hline Fram Strait, $75-78^{\circ} \mathrm{N}$ & $0-20$ & $>80 \%$ & $\begin{array}{l}\text { Inc (DO), } 24 \mathrm{~h} \text {, } \\
\text { in situ }\end{array}$ & Apr-May 2008 & & & & S11 \\
\hline Site $\mathrm{C} 1,78^{\circ} \mathrm{N}$ & & & & & +0.056 & & bd & \\
\hline Site E, $75^{\circ} \mathrm{N}$ & & & & & -0.006 & +0.029 & 0.031 & \\
\hline Fram Strait, $77-79^{\circ} \mathrm{N}$ & $0-20$ & heavy & $\begin{array}{l}\text { Inc (DO), } \\
24 \mathrm{~h} \text { in situ }\end{array}$ & Apr 2007 & $+0.054 \pm 0.027$ & $+0.024 \pm 0.012$ & $0.025 \pm 0.012$ & V13 \\
\hline $\begin{array}{l}\text { Lillefjord, } \\
\text { W Greenland, } 70^{\circ} \mathrm{N}\end{array}$ & & & & Feb-Mar 2013 & & & & \\
\hline \multirow[t]{2}{*}{ Fjord edge } & Surface & $100 \%$ & $\begin{array}{l}\text { Inc (DO) in situ, } \\
1-4 d\end{array}$ & & $-0.17 \pm 0.19$ & $+0.19 \pm 0.30$ & $0.36 \pm 0.24$ & This study \\
\hline & & & Ambient DO & & $-0.001 \pm 0.031$ & & & \\
\hline \multirow[t]{2}{*}{ Fjord centre } & Surface & $100 \%$ & $\begin{array}{l}\text { Inc (DO) in situ, } \\
1-4 d\end{array}$ & & $-0.10 \pm 0.07$ & $-0.01 \pm 0.10$ & $0.09 \pm 0.07$ & \\
\hline & & & Ambient DO & & $+0.023 \pm 0.013$ & & & \\
\hline
\end{tabular}

Abbreviations are as follows: inc: incubations using DO or ${ }^{14} \mathrm{C}$; bd: below level of detection; NM: not measured; NR: measured but not reported. Sources are listed as follows: G97, Gosselin et al. (1997); R99, Rysgaard et al. (1999); S03, Sherr and Sherr (2003); H05, Hill and Cota (2005); C06, Cottrell et al. (2006); M08, Mikkelsen et al. (2008); S11, Seuthe et al. (2011); and V13, Vaquer-Sunyer et al. (2013). ${ }^{a}$ Estimated from Fig. 2 in this paper. ${ }^{b}$ Calculated using authors' range of $9-57 \mathrm{~g} \mathrm{C} \mathrm{m}^{-2} \mathrm{~d}^{-1}$ over estimated depth of $60 \mathrm{~m}$ and reported as the mean \pm 1 standard deviation of the values in Table 2 in this paper.

measurements will allow us to better understand marine productivity and quantify its contribution to Arctic marine ecosystems. Here we present in situ observations of microbial metabolism made under continuous sea ice cover at $\sim 70^{\circ} \mathrm{N}$ in a west Greenland fjord (Lillefjord), derived from changes in DO measured in incubation experiments and in ambient seawater during February-March 2013, shortly after the transition from polar night to spring conditions on 21 January.

\section{Field site and methods}

Measurements were made in Lillefjord, west Greenland $\left(70^{\circ} 30^{\prime} \mathrm{N}, 50^{\circ} 40^{\prime} \mathrm{W}\right)$. Lillefjord is $16 \mathrm{~km}$ long branch of the Uummannaq Fjord system, which opens to Baffin Bay approximately $70 \mathrm{~km}$ from the field site. The fjord system (including Lillefjord itself) receives meltwater runoff and calving icebergs from several outlet glaciers that drain the Greenland Ice Sheet, in common with many similar fjords in Greenland. In the winter of 2012/2013, continuous sea ice in Lillefjord had not formed until late January, which, although similar to several immediately preceding winters, was con- 

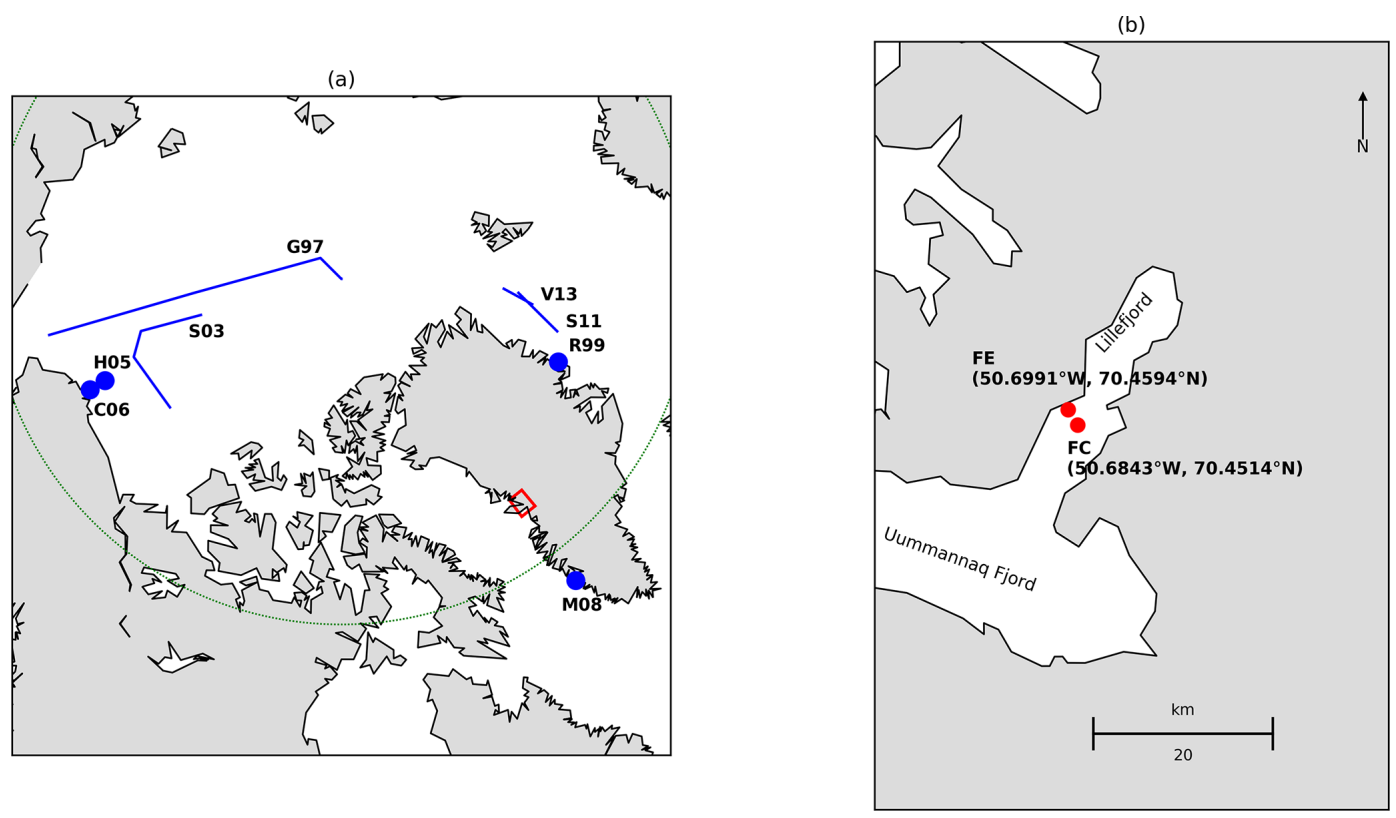

Figure 1. (a) Locations where microbial metabolism has been measured in the water column under sea ice (minimum sea ice cover $80 \%$ ). Abbreviations follow Table 1. Positions of points and transects are approximate and are based on maps in the corresponding publications. The Arctic Circle is marked in green and the red box shows the location of Lillefjord, west Greenland. (b) Location of the fjord edge (FE) and fjord centre (FC) study sites. Coastline data are from https://www.soest.hawaii.edu/pwessel/gshhg/ (last access: 17 April 2020 , Wessel and Smith, 1996).

sidered locally to be unusually late (fishermen in Uummannaq Fjord, personal communication, 2013).

Data were collected at two sites approximately mid-way between the calving front at the head of Lillefjord and the confluence of Lillefjord with Uummannaq Fjord (Fig. 1). Hole 1 (fjord edge) was approximately $50 \mathrm{~m}$ from the shore, in water 5-10 $\mathrm{m}$ deep; hole 2 (fjord centre) was located centrally in the fjord in water $\sim 300 \mathrm{~m}$ deep (Jakobsson et al., 2012). The sea ice thickness was initially measured as approximately $27 \mathrm{~cm}$ at both sites and increased slightly (by less than $10 \mathrm{~cm}$ ) during the study period. Snow was absent from the sea ice until 13 February and then present in variable amounts thereafter (changes in these conditions are reported in Table 2).

Rates of photosynthesis and respiration were quantified using in situ incubation experiments in the uppermost $\sim 30 \mathrm{~cm}$ of the water column under the sea ice, based on measured changes in the DO content of seawater samples. A total of 13 experiments were carried out between 6 February and 6 March 2013. In each experiment, up to 10 samples of seawater were collected and incubated in situ under the sea ice in $250 \mathrm{~mL}$ biological oxygen demand (BOD) bottles. Half the bottles were wrapped in tin foil to make them opaque to light (dark bottles), and the remainder were left unwrapped and transparent to light (light bottles). It was assumed that no photosynthesis took place in the dark bottles, so any changes in $\mathrm{DO}$ between the start and end of the experiment $\left(\Delta \mathrm{DO}_{\text {dark }}\right)$ are attributed solely to community respiration (CR). Both respiration and photosynthesis can occur in light bottles, so the change in $\mathrm{DO}\left(\Delta \mathrm{DO}_{\text {light }}\right)$ is assumed to indicate net community production (NCP). Rates of gross primary productivity (GPP), inferred to be photosynthesis, are estimated using the difference in $\triangle \mathrm{DO}$ between the light and dark bottles, i.e. NCP-CR. This is a standard and well-established method for measuring rates of microbial metabolism in freshwater and marine ecosystems (Sherr and Sherr, 2003; Cottrell et al., 2006; Vaquer-Sunyer et al., 2013).

To begin each experiment, a hole of approximately $30 \mathrm{~cm}$ diameter was cut in the sea ice, using hand tools to avoid oil contamination. Water salinity and temperature were measured using a WTW handheld electrical conductivity (EC) meter (manufacturer's stated accuracy: temperature $\pm 0.1^{\circ} \mathrm{C}$; $\mathrm{EC} \pm 0.5 \%$ ), and the approximate ice thickness and overlying undisturbed snow depth were measured using a ruler. Both the ice thickness and snow depth were disturbed by the opening and reopening of the hole, so the measurements made at the start of each experiment should only be interpreted as indicative of the general ambient conditions. A metal sieve was used throughout sample collection to remove ice debris from the water surface in the hole, to prevent ice fragments from entering the sample bottles. Due to the typically cold air temperatures $\left(-25\right.$ to $\left.-5^{\circ} \mathrm{C}\right)$, the bottles were kept warm before use by adding $\sim 20 \mathrm{~mL}$ of boiling seawater to each bottle prior to transport to the field site; the bottles were then kept in an insulated box until needed. This was important to avoid the seawater freezing directly onto the cold 
Table 2. Summary of results obtained in the incubation experiments at the two holes FE (fjord edge) and FC (fjord centre). Quoted values are means with $95 \%$ confidence intervals, except when $N=2$ (as indicated by ${ }^{*}$ ), where the error bounds are simply the range of the two observations. $T$ is the duration of the incubation, $N$ is the number of samples, and $L-D$ is the difference between the change in dissolved oxygen in the light bottles, and in the dark bottles $\left(\Delta \mathrm{DO}_{\text {light }}-\Delta \mathrm{DO}_{\text {dark }}\right)$.

\begin{tabular}{|c|c|c|c|c|c|c|c|c|c|}
\hline $\begin{array}{l}\text { Start time } \\
(2013)\end{array}$ & Hole & $\begin{array}{r}T \\
(\mathrm{~d})\end{array}$ & $\begin{array}{r}\mathrm{O}_{2} \text { start } \\
\left(\mathrm{g} \mathrm{O}_{2} \mathrm{~m}^{-3}\right)\end{array}$ & $N_{\mathrm{L}}$ & $\begin{array}{r}\Delta \mathrm{DO}_{\text {light }} \\
\left(\mathrm{g} \mathrm{O}_{2} \mathrm{~m}^{-3} \mathrm{~d}^{-1}\right)\end{array}$ & $N_{\mathrm{D}}$ & $\begin{array}{r}\Delta \mathrm{DO}_{\text {dark }} \\
\left(\mathrm{g} \mathrm{O}_{2} \mathrm{~m}^{-3} \mathrm{~d}^{-1}\right)\end{array}$ & $\begin{array}{r}L-D \\
\left(\mathrm{~g} \mathrm{O}_{2} \mathrm{~m}^{-3} \mathrm{~d}^{-1}\right)\end{array}$ & Notes \\
\hline $6 \mathrm{Feb}, 17: 25$ & FE & 1.0 & $12.00 \pm 0.06$ & 4 & $0.17 \pm 0.24$ & 4 & $-0.14 \pm 0.14$ & $0.31 \pm 0.28$ & Cloudy throughout experiment. \\
\hline $8 \mathrm{Feb}, 17: 57$ & $\mathrm{FE}$ & 1.0 & $12.44 \pm 0.25$ & 4 & $-0.74 \pm 0.90$ & 4 & $-0.94 \pm 0.40$ & $0.21 \pm 0.98$ & $\begin{array}{l}\text { Cloudy throughout experiment. } \\
\text { Calving event caused risk of ice } \\
\text { break-up at experiment start, before } \\
\text { all bottles filled. }\end{array}$ \\
\hline $13 \mathrm{Feb}, 18: 30$ & $\mathrm{FE}$ & 1.0 & $12.31 \pm 0.04$ & 5 & $-0.08 \pm 0.07$ & 4 & $-0.17 \pm 0.24$ & $0.09 \pm 0.25$ & $\begin{array}{l}\text { Clear at start but overcast by mid- } \\
\text { morning of } 14 \mathrm{Feb} \text {, and cloud } \\
\text { steadily increased all day. }\end{array}$ \\
\hline $21 \mathrm{Feb}, 19: 47$ & FE & 4.0 & $12.37 \pm 0.12^{*}$ & 2 & $-0.12 \pm 0.05^{*}$ & - & - & - & $20-30 \mathrm{~mm}$ fresh snow. Clear sky. \\
\hline 4 Mar, 20:45 & $\mathrm{FE}$ & 2.0 & $12.12 \pm 0.06$ & 3 & $-0.08 \pm 0.03$ & 2 & $-0.02 \pm 0.10$ & $-0.05 \pm 0.10$ & $\begin{array}{l}\text { Thin covering of wind-scoured snow. } \\
\text { Clear sky. }\end{array}$ \\
\hline Overall & $\mathrm{FE}$ & & $12.24 \pm 0.08$ & 18 & $-0.17 \pm 0.19$ & 14 & $-0.36 \pm 0.24$ & $0.19 \pm 0.30$ & \\
\hline $10 \mathrm{Feb}, 17: 40$ & $\mathrm{FC}$ & 1.1 & $12.13 \pm 0.15$ & 5 & $-0.26 \pm 0.30$ & 4 & $-0.38 \pm 0.22$ & $0.12 \pm 0.37$ & $\begin{array}{l}\text { Clear on } 10 \text { Feb. Partly cloudy on } \\
11 \text { Feb. }\end{array}$ \\
\hline $12 \mathrm{Feb}, 10: 03$ & $\mathrm{FC}$ & 1.0 & $12.24 \pm 0.13$ & 5 & $-0.08 \pm 0.07$ & 5 & $-0.17 \pm 0.19$ & $0.09 \pm 0.20$ & $\begin{array}{l}\text { Thin layer of snow. Clear morning on } \\
12 \text { Feb, cloudy afternoon. }\end{array}$ \\
\hline $15 \mathrm{Feb}, 17: 45$ & $\mathrm{FC}$ & 1.0 & $12.38 \pm 0.05$ & 5 & $0.03 \pm 0.08$ & 5 & $0.09 \pm 0.11$ & $-0.06 \pm 0.14$ & Thin layer of snow. \\
\hline $17 \mathrm{Feb}, 18: 38$ & FC & 1.1 & $12.32 \pm 0.05$ & 5 & $-0.01 \pm 0.08$ & 5 & $0.08 \pm 0.21$ & $-0.10 \pm 0.22$ & $\begin{array}{l}5-10 \mathrm{~mm} \text { fresh snow. Overcast on } \\
17 \mathrm{Feb} \text {. Cloudy but bright on } 18 \mathrm{Feb} \text {. }\end{array}$ \\
\hline $19 \mathrm{Feb}, 19: 23$ & $\mathrm{FC}$ & 1.1 & $12.52 \pm 0.08$ & 5 & $-0.12 \pm 0.14$ & 5 & $-0.08 \pm 0.16$ & $-0.04 \pm 0.21$ & $\begin{array}{l}20-30 \mathrm{~mm} \text { snow. High cloud and sun- } \\
\text { shine in morning of } 20 \mathrm{Feb} \text {, then in- } \\
\text { creasing cloud. }\end{array}$ \\
\hline $24 \mathrm{Feb}, 20: 36$ & $\mathrm{FC}$ & 0.9 & $12.58 \pm 0.01^{*}$ & 2 & $-0.10 \pm 0.03^{*}$ & - & - & - & 30-30 mm snow. Clear sky. \\
\hline 25 Feb, 21:29 & $\mathrm{FC}$ & 1.8 & $12.61 \pm 0.20$ & 2 & $-0.27 \pm 0.03^{*}$ & 3 & $-0.32 \pm 0.21$ & $0.05 \pm 0.42$ & $\begin{array}{l}10-20 \mathrm{~mm} \text { snow. Clear sky on } 25 \text { and } \\
26 \text { Feb. Cloud increasing on } 27 \text { Feb. }\end{array}$ \\
\hline $28 \mathrm{Feb}, 18: 22$ & $\mathrm{FC}$ & 2.1 & $12.49 \pm 0.14$ & 5 & $-0.10 \pm 0.10$ & 5 & $-0.03 \pm 0.17$ & $-0.08 \pm 0.20$ & $\begin{array}{l}10-20 \text { mm snow, partially melted on } \\
28 \text { Feb. Overcast } 28 \text { Feb and } 1 \text { Mar, } \\
\text { snow showers on } 1 \text { Mar. Clear on } \\
2 \text { Mar. }\end{array}$ \\
\hline Overall & $\mathrm{FC}$ & & $12.38 \pm 0.05$ & 34 & $-0.10 \pm 0.07$ & 32 & $-0.09 \pm 0.07$ & $-0.01 \pm 0.10$ & \\
\hline
\end{tabular}

glass, which could have caused formation of ice inside the bottle or compromised the seal around the stopper. Immediately prior to sampling, each bottle was rinsed three times with seawater taken from the hole. The bottles were then refilled with water from the hole and suspended just under the water surface (to prevent ice from forming on the inside of the bottle). The water temperature and DO content in the bottle were measured using a PreSens Fibox 3 fibre-optic oxygen meter (manufacturer's stated accuracy: $\pm 1 \%$ ), which outputs data every $1 \mathrm{~s}$. To measure the DO in each bottle, the sensor was allowed to stabilise (normally within $60 \mathrm{~s}$ ), and readings were then taken for a further $20 \mathrm{~s}$. The mean of these readings was recorded as the initial DO for the sample. After making the measurements, the bottle was immediately sealed with a glass stopper. The stoppers are buoyant, so a small piece of tin foil was wrapped over the stopper to keep it in place. The Fibox3 sensor control unit often stops functioning at cold temperatures, so it was kept warm in the insulated box with the preheated bottles. Bottles were checked carefully once filled and sealed to ensure that no air bubbles were present. They were then left suspended on nylon ropes approximately
$50 \mathrm{~cm}$ below the ice surface. Bottles were left in place for periods of 24-96 h. After the allocated time, the hole was carefully reopened and the bottles retrieved and transferred to an insulated box for transport back to the field base. It was not practical to make the final DO measurements at the incubation site because, after being removed from the sea, the water in the bottles would have started to freeze in the time taken to record the measurements. Therefore, the sealed bottles were transported in an insulated carrier to the field base, where the final DO and temperature were measured using the same Fibox3 sensor and probe. As for the initial DO measurements, the mean of readings made for $20 \mathrm{~s}$ after the sensor had stabilised were recorded as the final DO for the sample. The time between extraction from the hole and DO measurement was approximately $1 \mathrm{~h}$, and temperature data showed the water temperature in the bottles to have increased by less than $2{ }^{\circ} \mathrm{C}$ between removal from the incubation site and completion of the last measurement at the field base.

The main problems encountered during sample installation and recovery were associated with the cold air temperatures, which sometimes caused equipment failure (Fibox sys- 
tem and/or netbook) or caused ice crystals to form in bottles. On 8 February we were interrupted when filling the bottles, by a calving event which threatened to cause break-up of the sea ice. Therefore, we were not always able to obtain results from the full set of 10 bottles (as indicated by $N_{\mathrm{L}}$ and $N_{\mathrm{D}}$ in Table 2).

Incubation times were initially chosen as $24 \mathrm{~h}$, corresponding to one diurnal cycle. Since we were finding high variability in the early incubations, we also carried out some longer incubations ( 2 or $4 \mathrm{~d}$ ) later in the study period. While these longer incubations allowed for potentially greater changes in DO (i.e. a lower signal-to-noise ratio), we also note that longer incubations increase the effects of methodological artefacts associated with the incubations being a closed rather than open system. We do not have enough data to confidently assess what the optimum incubation time would be.

When converting between oxygen demand and carbon storage in Table 1, a 1:1 stoichiometric ratio between $\mathrm{CO}_{2}$ and $\mathrm{O}_{2}$ was used, although this ratio is noted to be subject to some uncertainty (Telling et al., 2010). We note that interpretation of the measurements would benefit from simultaneous measurements of microbial biomass; however, facilities for measuring biomass were not available at the field site.

\section{Uncertainty calculations}

After each experiment, the difference between initial and final DO was calculated for each bottle, and the mean $(\mu)$ and standard deviation $(\sigma)$ of the differences were used to infer the change in DO $(\Delta \mathrm{DO})$. The number of bottles $(n)$ in any one experiment was small, so it is appropriate to use a $t$ distribution when calculating the $95 \%$ confidence interval for $\Delta \mathrm{DO}$. Treating light and dark bottles separately, $\Delta \mathrm{DO}$ was divided by the incubation time ( $T$ ) to give the rate of change in DO, $\Delta \mathrm{DO} / T$ as shown in Eq. (1), where $t$ is the critical value of the $t$ distribution at the $95 \%$ confidence level.

$\Delta \mathrm{DO} / T=\left[\mu \pm t \sigma(n-1)^{-0.5}\right] / T$

The confidence intervals for $\Delta \mathrm{DO}_{\text {light }}$ and $\Delta \mathrm{DO}_{\text {dark }}$ were propagated through the calculations for rates of NCP, CR and photosynthesis. Each of these rates is therefore reported with an uncertainty corresponding to the limits of the $95 \%$ confidence interval and is considered significant if zero lies outside the interval.

The mean and standard deviation of the initial DO measured in all the bottles (light and dark) were used to quantify the ambient DO and associated $95 \%$ confidence interval for the seawater at each experiment start time, again using the $t$ distribution as in Eq. (1). A linear fit was then applied to the time series of ambient DO at each study site, using linear least-squares regression. The gradient of the fit represents the mean rate of change in ambient DO over the study period and is reported with the $95 \%$ confidence interval calculated using the $t$ distribution and regression parameters.

\section{Results}

Throughout the study period, the seawater temperature and salinity varied between -1.5 and $-1.7^{\circ} \mathrm{C}$ and between 32.6 and $32.8 \mathrm{psu}$, respectively. The mean $\pm 1 \sigma$ DO of ambient seawater was $12.24 \pm 0.23 \mathrm{~g} \mathrm{O}_{2} \mathrm{~m}^{-3}$ (fjord edge) and $12.38 \pm 0.20 \mathrm{~g} \mathrm{O}_{2} \mathrm{~m}^{-3}$ (fjord centre). Linear regression analysis yielded no significant change in DO with time during the study period at the fjord edge $\left(-0.001 \pm 0.031 \mathrm{~g} \mathrm{O}_{2} \mathrm{~m}^{-3} \mathrm{~d}^{-1}\right)$, while at the fjord centre there was a statistically significant increase in DO at a rate of $0.023 \pm 0.013 \mathrm{~g} \mathrm{O}_{2} \mathrm{~m}^{-3} \mathrm{~d}^{-1}$, equivalent to $720 \pm$ $410 \mathrm{nMO}_{2} \mathrm{~d}^{-1}$ (Fig. 2a).

For each incubation experiment, the changes in DO $(\triangle \mathrm{DO})$ measured for each of the individual light and dark bottles were averaged to give a mean $\Delta \mathrm{DO}_{\text {light }}$ and $\Delta \mathrm{DO}_{\text {dark }}$ for the experiment. For three out of the five incubation experiments at the fjord edge, and three out of the eight experiments at the fjord centre, $\Delta \mathrm{DO}_{\text {light }}$ showed a significant decrease (Table 2, Fig. 2b). $\Delta \mathrm{DO}_{\text {dark }}$ showed a significant decrease for two out of four experiments at the fjord edge and for two out of seven experiments at the fjord centre (Fig. 2c).

Results for all the bottles in all the incubations were grouped together (averaging the rates of change in DO for all light bottles and all dark bottles separately) to reflect mean conditions over the whole study period. This was done separately for the two study sites. We found a significant decrease in DO for the dark bottles at the fjord edge and for both the light and dark bottles at the fjord centre $\left(-0.36 \pm 0.24 \mathrm{~g} \mathrm{O}_{2} \mathrm{~m}^{-3} \mathrm{~d}^{-1}\right.$ for dark bottles at the fjord edge; $-0.10 \pm 0.07$ and $-0.09 \pm 0.07 \mathrm{~g} \mathrm{O}_{2} \mathrm{~m}^{-3} \mathrm{~d}^{-1}$ for light and dark bottles at the fjord centre). There was no significant change in DO for light bottles at the fjord edge.

For each incubation experiment, the difference between $\triangle \mathrm{DO}$ calculated for the light and for the dark bottles is interpreted as GPP. None were found to be significantly different from zero (Fig. 2d) except for the first experiment at the fjord edge, where the $95 \%$ confidence interval for GPP was $0.31 \pm 0.28 \mathrm{~g} \mathrm{O}_{2} \mathrm{~m}^{-3} \mathrm{~d}^{-1}$.

\section{Discussion}

Significant decreases in DO in the dark incubations at both sites are attributed to microbial respiration (Fig. $2 \mathrm{c}$ and Table 2). This is consistent with the few previous observations of microbial metabolism under sea ice cover, which have found significant CR (Table 1), and is not unexpected given the persistence of microbial communities through the polar night (Berge et al., 2015); however, in Lillefjord the measured rates (particularly at the fjord edge) are considerably higher than those at other ice-covered sites (Table 1). In common with most previous studies (both open water and ice covered; see Sect. 1 and Table 1), our observations have high standard deviations. 

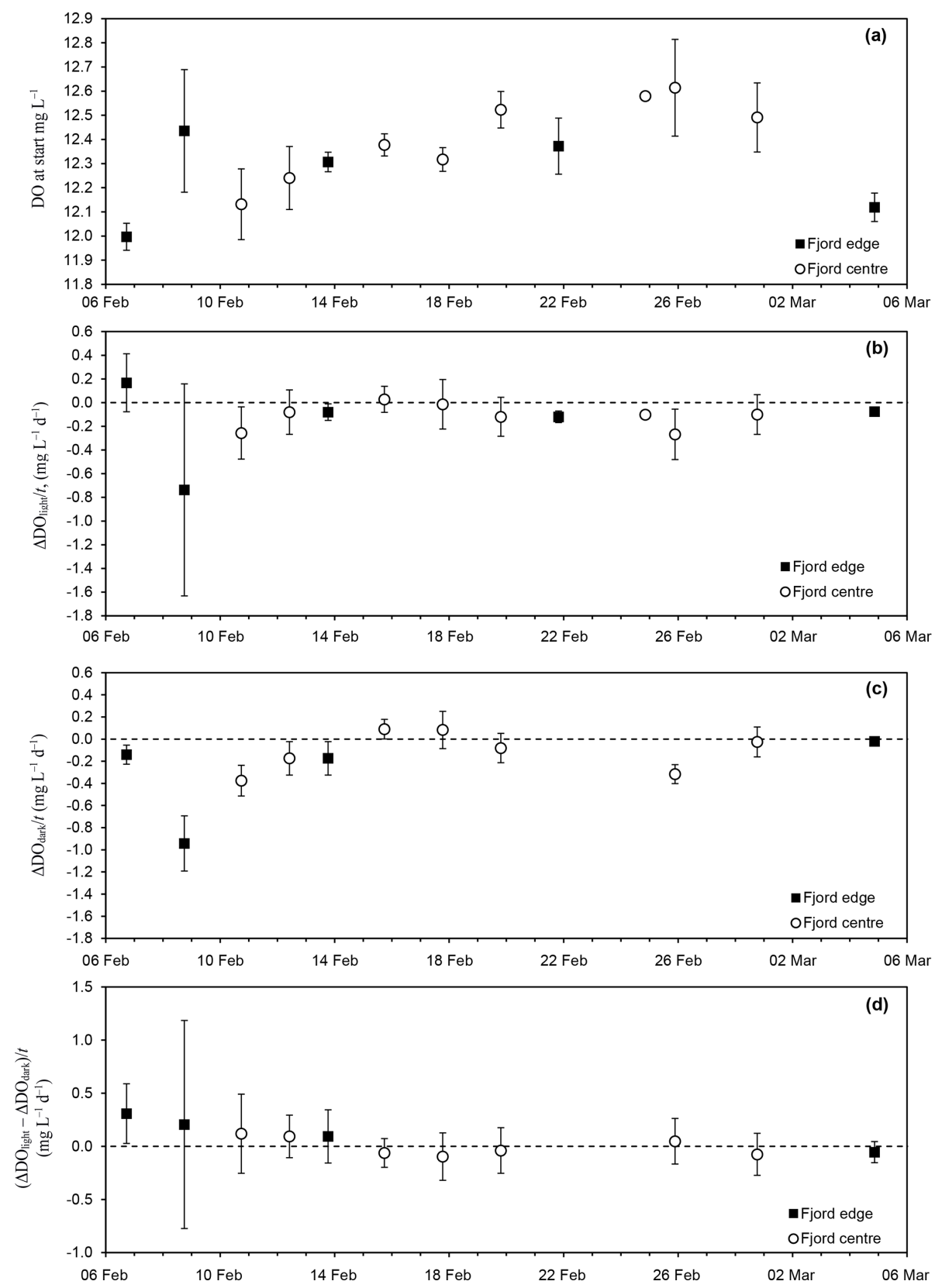

Figure 2. Time series of (a) ambient DO concentration in the seawater at the start of each experiment; (b) rate of change of DO in the light incubation bottles $\left(\Delta \mathrm{DO}_{\text {light }} / T\right)$, interpreted as the net community production rate $(\mathrm{NCP})$; (c) rate of change of DO in the dark incubation bottles $\left(\Delta \mathrm{DO}_{\text {dark }} / T\right)$, interpreted as the respiration rate $(\mathrm{CR})$; and $(\mathbf{d})$ the difference $\left(\Delta \mathrm{DO}_{\text {light }}-\Delta \mathrm{DO}_{\text {dark }}\right) / T$, interpreted as the photosynthesis rate (GPP). Times are local time in Greenland (UTC-3) in 2013.

The rate of change in DO in the light bottles (considered to represent NCP) was either weakly negative or insignificant. These results for NCP at Lillefjord are consistent with observations from the one other west Greenland fjord studied during February-March, to our knowledge ( $\mathrm{NCP}<0.001 \mathrm{~g} \mathrm{O}_{2} \mathrm{~m}^{-3} \mathrm{~d}^{-1}$ at Kangerluarsunnguaq in subArctic SW Greenland; Mikkelsen et al., 2008). They are also consistent with some studies of ice-covered open-ocean sites (Sherr and Sherr, 2003; Hill and Cota, 2005) but contrast with others (weakly positive NCP was reported by Cottrell et al., 2006, in the Arctic Ocean and by Vaquer-Sunyer et al., 2013, in the Fram Strait). With the exception of Sherr and Sherr (2003), measurements at these ice-covered ocean sites were collected later in the year (mid-April to June) than those at Lillefjord.

The lack of any significant difference between $\Delta \mathrm{DO}$ in the light and dark bottles means that there was no significant evidence for GPP (or photosynthesis). This should not 
be interpreted as significant evidence for no photosynthesis, particularly given the high variance in the data indicated by wide $95 \%$ confidence intervals; however, it does show that the rate of photosynthesis - if it was occurring - must have been much smaller than that of respiration. For comparison, Rysgaard et al. (1999) and Mikkelsen et al. (2008) both found evidence for very low rates of photosynthesis under sea ice in fjords shortly before ice breakup $\left(\mathrm{GPP}<0.003 \mathrm{~g} \mathrm{O}_{2} \mathrm{~m}^{-3} \mathrm{~d}^{-1}\right.$ in Young Sound, Rysgaard et al., 1999; $\mathrm{NCP}=+0.001 \mathrm{~g} \mathrm{O}_{2} \mathrm{~m}^{-3} \mathrm{~d}^{-1}$ in Kangerluarsunnguaq, Mikkelsen et al., 2008). Other studies have found evidence for significant GPP in the largely (>80\%) icecovered open ocean in the Fram Strait during April-May, which contributed to an overall positive NCP (Seuthe et al., 2011; Vaquer-Sunyer et al., 2013). Under continuous firstyear sea ice in Franklin Bay (a coastal site at a similar latitude to Lillefjord), Terrado et al. (2008) observed an increase in the abundance of photosynthetic organisms as early as February in response to increasing surface irradiance. Similarly, chlorophyll $a$ concentrations were observed to reach a minimum in January and to begin increasing in February, within first-year sea ice in the open Arctic Ocean in the Canada Basin (Melnikov et al., 2002). In Lillefjord, it is not clear whether the photosynthetic activity in the surface waters had not commenced during the study period or was masked by the stronger and highly variable respiration signal.

In contrast to the incubation results, there was a significant increase in ambient DO at the fjord centre of $0.023 \pm$ $0.013 \mathrm{~g} \mathrm{O}_{2} \mathrm{~m}^{-3} \mathrm{~d}^{-1}$. This differs from the findings of Sherr and Sherr (2003), where a decrease was observed in ambient DO under sea ice during winter in the western Arctic Ocean. Lillefjord was completely ice covered during the study period, preventing any air-water gas exchange, and no decrease in DO was observed in the incubation experiments. Therefore, the increase in ambient DO may have been due to processes not occurring in the incubations (such as sea algal photosynthesis on the underside of the sea ice). These contrasting results from simultaneous incubation and in situ experiments demonstrate the advantage of using both closed and open techniques when there is continuous ice cover.

Despite the increasing surface irradiance (longer daylight hours and less shading by surrounding topography at higher solar elevations), the incubation experiments provide no evidence for temporal changes in metabolism rates. It is possible that some of the increase in incident radiation at the snow/ice surface did not reach the water below the ice because of increases in snow cover and ice thickness over this same period. Without under-ice irradiance measurements this is necessarily uncertain; however, the radiation intensity $S$ reaching the water column (as a fraction of surface incident radiation intensity $S_{0}$ ) can be estimated using $S / S_{0}=$ $(1-\alpha) \exp \left(-k_{\mathrm{s}} z_{\mathrm{s}}-k_{i} z_{i}\right)$, where $\alpha$ is the surface albedo, and $z_{\mathrm{s}, i}$ and $k_{\mathrm{s}, i}$ are the thicknesses and extinction coefficients for snow and ice, respectively. Assuming extinction coefficients of 4.8 and $0.9 \mathrm{~m}^{-1}$ for snow and sea ice, and albedos of 0.90 and 0.65 for fresh snow and sea ice (following Mikkelsen et al., 2008), the under-ice irradiance is estimated as $31 \%$ of the surface irradiance before snowfall on 14 February and $11 \%$ afterwards. Therefore, increases in surface irradiance in early February as experienced under the ice could have been considerably reduced following snowfall in mid February.

\section{Data availability}

The data are archived at PANGAEA (https://doi.org/10.1594/PANGAEA.906332, Chandler and Mackie, 2019).

\section{Conclusions}

These data provide a first indication of winter microbial metabolism beneath sea ice in an Arctic fjord in west Greenland. Thirteen in situ incubation experiments provide strong evidence for microbial respiration at rates 2-20 times higher than those reported under sea ice elsewhere in the Arctic (see Table 1). The high variance in the NCP and CR results (both between individual bottles in one experiment and between incubations) is a common characteristic of marine microbial metabolism measurements under sea ice (Table 1) and presents a challenge to accurate calculation of GPP or temporal trends. This variance should be carefully accounted for when considering uncertainties associated with estimates of the regional-scale contributions of microbial activity, which are necessarily based on the limited data that are currently available. In future studies this could be addressed by increasing the number of bottles and/or conducting more frequent experiments and by extending the study period to obtain a longer time series. Finally, the contrast between the increasing trend in ambient seawater DO and the net oxygen decrease in the incubation experiments highlights potential differences between controlled and open experiments. In this study, the difference is most likely attributable to net production by sea ice algae (which would increase DO in the ambient seawater), contrasting with net respiration in the underlying water (which would decrease the DO in the closed incubations). This suggests an earlier onset of photosynthesis at the underside of the sea ice than in the underlying water.

Author contributions. Both authors contributed equally to data collection, data analysis and preparation of the paper.

Competing interests. The authors declare that they have no conflict of interest.

Acknowledgements. The authors would like to thank Alun Hubbard and the Uummannaq Polar Institute for their logistical support. 
This research did not receive any specific grant from funding agencies in the public, commercial or not-for-profit sectors.

Review statement. This paper was edited by Jens Klump and reviewed by three anonymous referees.

\section{References}

Arrigo, K. R., van Dijken, G., and Pabi, S.: Impact of a shrinking Arctic ice cover on marine primary production, Geophys. Res. Lett., 35, L19603, https://doi.org/10.1029/2008GL035028, 2008.

Assmy, P., Fernández-Méndez, M., Duarte, P., Meyer, A., Randelhoff, A., Mundy, C. J., Olsen, L. M., Kauko, H. M., Bailey, A., Chierici, M., Cohen, L., Doulgeris, A. P., Ehn, J. K., Fransson, A., Gerland, S., Hop, H., Hudson, S. R., Hughes, N., Itkin, P., Johnsen, G., King, J. A., Koch, B. P., Koenig, Z., Kwasniewski, S., Laney, S. R., Nicolaus, M., Pavlov, A. K., Polashenski, C. M., Provost, C., Rösel, A., Sandbu, M., Spreen, G., Smedsrud, L. H., Sundfjord, A., Taskjelle, T., Tatarek, A., Wiktor, J., Wagner, P. M., Wold, A., Steen, H., and Granskog, M. A.: Leads in Arctic pack ice enable early phytoplankton blooms below snow-covered sea ice, Sci. Rep., 7, 40850, https://doi.org/10.1038/srep40850, 2017.

Attard, K. M., Glud, R. N., McGinnis, D. F., and Rysgaard, S.: Seasonal rates of benthic primary production in a Greenland fjord measured by aquatic eddy correlation, Limnol. Oceanogr., 59, 1555-1569, https://doi.org/10.4319/lo.2014.59.5.1555, 2014.

Belzille, C., Brugel, S., Nozais, C., Gratton, Y., and Demers, S.: Variations of the abundance and nucleic acid content of heterotrophic bacteria in Beaufort Shelf waters during winter and spring, J. Marine Syst. 74, 946-956, 2008.

Berge, J., Renaud, P. E., Darnis, G., Cottier, F., Last, K., Gabrielsen, T. M., Johnsen, G., Seuthe, L., Weslawski, J. M., Leu, E., Moline, M., Nahrgang, J., Søreide, J. E., Varpe, Ø., Lønne, O. J., Daase, M., and Falk-Petersen, S.: In the dark: A review of ecosystem processes during the polar night, Prog. Oceanogr., 139, 258-271, https://doi.org/10.1016/j.pocean.2015.08.005, 2015.

Brown, Z. W. and Arrigo, K. R.: Contrasting trends in sea ice and primary production in the Bering Sea and Arctic Ocean, ICES J. Mar. Sci., 69, 1180-1193, https://doi.org/10.1093/icesjms/fss113, 2012.

Chandler, D. and Mackie, S.: Observations of winter marine productivity in an ice-covered fjord, West Greenland, PANGAEA, https://doi.pangaea.de/10.1594/PANGAEA.906332, 2019.

Chandler, D. and Mackie, S.: Observations of winter marine microbial activity in an ice-covered fjord, West Greenland, PANGAEA, https://doi.pangaea.de/10.1594/PANGAEA.912677, 2020.

Comiso, J. C. and Hall, D. K.: Climate trends in the Arctic as observed from space, WIRES Clim. Change, 5, 389-409 https://doi.org/10.1002/wcc.277, 2014.

Cottrell, M. T., Malmstrom, R. R., Hill, V., Parker, A. E., and Kirchman, D. L.: The metabolic balance between autotrophy and heterotrophy in the western Arctic Ocean, Deep-Sea Res. Pt. I, 53, 1831-1844, 2006.

Flynn, K. J., Stoecker, D. K., Mitra, A., Raven, J. A., Glibert, P. M., Hansen, P. J., Granéli, E., and Burkholder, J. M.: Misuse of the phytoplankton-zooplankton dichotomy: the need to assign organisms as mixotrophs within plankton functional types, J. Plankton Res., 35, 3-11, https://doi.org/10.1093/plankt/fbs062, 2013.

Glud, R. N., Kühl, M., Wenzhöferl, F., and Rysgaard, S.: Benthic diatoms of a high Arctic fjord (Young Sound, NE Greenland): importance for ecosystem primary production, Mar. Ecol. Prog. Ser., 238, 15-29, 2002.

Gosselin, M., Levasseur, M., Wheeler, P. A., Horner, R. A., and Booth, B. C.: New measurements of phytoplankton and ice algal production in the Arctic Ocean, Deep-Sea Res. Pt. II, 44, 16231644, 1997.

Hansen, A. S., Nielsen, T. G., Levinsen, H., Madsen, S. D., Thingstad, T. F., and Hansen, B. W.: Impact of changing ice cover on pelagic productivity and food web structure in Disko Bay, West Greenland: a dynamic model approach, Deep-Sea Res. Pt. I, 50, 171-187, 2003.

Hawkings, J. R., Wadham, J. L., Tranter, M., Raisewell, R., Benning, L. G., Stratham, P. J., Tedstone, A., Nieniow, P., Lee, K., and Telling, J.: Ice sheets as a significant source of highly reactive nanoparticulate iron to the oceans, Nat. Commun., 5, 3929, https://doi.org/10.1038/ncomms4929, 2014.

Hill, V. and Cota, G.: Spatial patterns of primary production on the shelf, slope and basin of the Western Arctic in 2002, Deep-Sea Res. Pt. II, 52, 3344-3354, 2005.

Jakobsson, M., Mayer, L., Coakley, B., Dowdeswell, J. A., Forbes, S., Fridman, B., Hodnesdal, H., Noormets, R., Pedersen, R., Rebesco, M., Schenke, H. W., Zarayskaya, Y., Accettella, D., Armstrong, A., Anderson, R. M., Bienhoff, P., Camerlenghi, A., Church, I., Edwards, M., Gardner, J. V., Hall, J. K., Hell, B., Hestvik, O., Kristoffersen, Y., Marcussen, C., Mohammad, R., Mosher, D., Nghiem, S. V., Pedrosa, M. T., Travaglini, P. G. and Weatherall, P.: The International Bathymetric Chart of the Arctic Ocean (IBCAO) Version 3.0, Geophys. Res. Lett., 39, L12609, https://doi.org/10.1029/2012GL052219, 2012.

Lawson, E. C., Wadham, J. L., Tranter, M., Stibal, M., Lis, G. P., Butler, C. E. H., Laybourn-Parry, J., Nienow, P., Chandler, D., and Dewsbury, P.: Greenland Ice Sheet exports labile organic carbon to the Arctic oceans, Biogeosciences, 11, 4015-4028, https://doi.org/10.5194/bg-11-4015-2014, 2014.

Matrai, P. A., Olson, E., Suttles, S., Hill, V., Codispoti, L. A., Light, B., and Steele, M.: Synthesis of primary production in the Arctic Ocean: I. Surface waters, 1954-2007, Prog. Oceanogr., 110, 93 106, https://doi.org/10.1016/j.pocean.2012.11.004, 2013.

McMeans, B. C., Rooney, N., Arts, M. T., and Fisk, A. T.: Food web structure of a coastal Arctic marine ecosystem and its implications for stability, Mar. Ecol. Prog. Ser., 482, 17-28, https://doi.org/10.3354/meps10278, 2013.

Meire, L., Mortensen, J., Meire, P., Juul-Pedersen, T., Sejr, M. K., Rysgaard, S., Nygaard, R., Huybrechts, P., and Meysman, F. J. R.: Marine-terminating glaciers sustain high productivity in Greenland fjords, Glob. Change Biol., 23, 5344-5357, https://doi.org/10.1111/gcb.13801, 2017.

Melnikov, I. G., Kolosova, E. G., Welch, H., and Zhitina, L. S.: Sea ice biological communities and nutrient dynamics in the Canada Basin of the Arctic Ocean, Deep-Sea Res. Pt. I, 49, 1623-1649, 2002.

Mikkelsen, D. E., Rysgaard, S., and Glud, R. N.: Microalgal composition and primary production in Arctic sea ice: a seasonal study 
from Kobbefjord (Kangerluarsunnguaq), West Greenland, Mar. Ecol. Prog. Ser., 368, 65-74, https://doi.org/10.3354/meps07627, 2008.

Pomeroy, L.: Primary production in the Arctic Ocean estimated from dissolved oxygen, J. Marine Syst., 10, 1-8, 1997.

Post, E., Bhatt, U. S., Bitz, C. M., Brodie, J. F., Fulton, T. L., Hebblethwaite, M., Kerby, J., Kutz, S. J., Stirling, I., and Walker, D. A.: Ecological consequences of sea ice decline, Science, 341, 519-524, https://doi.org/10.1126/science.1235225, 2013.

Regaudie-de-Gioux, A. and Duarte, C. M.: Plankton metabolism in the Greenland Sea during the polar summer of 2007, Pol. Biol., 33, 1651-1660, https://doi.org/10.1007/s00300-010-0792$1,2010$.

Rysgaard, S., Kühl, M., Glud, R. N., and Hansen, J. W.: Biomass, production and horizontal patchiness of sea ice algae in a highArctic fjord (Young Sound, NE Greenland), Mar. Ecol. Prog. Ser., 223, 15-26, 2001.

Rysgaard, S., Nielsen, T. G., and Hansen, B. W.: Seasonal variation in nutrients, pelagic primary production and grazing in a high-Arctic coastal marine ecosystem, Young Sound, Northeast Greenland, Mar. Ecol. Prog. Ser., 179, 13-25, 1999.

Seuthe, L., Töpper, B., Reigstad, M., Thyrhaug, R., and VaquerSunyer, R.: Microbial communities and processes in ice-covered Arctic waters of the northwestern Fram Strait $\left(75\right.$ to $\left.80^{\circ} \mathrm{N}\right)$ during the vernal pre-bloom phase, Aquat. Microb. Ecol., 64, 253266, https://doi.org/10.3354/ame01525, 2011.

Sherr, B. F. and Sherr, E. B.: Community respiration/production and bacterial activity in the upper water column of the central Arctic Ocean, Deep-Sea Res. Pt. I, 50, 529-542, 2003.

Sherr, E. B., Sherr, B. F., Wheeler, P. A., and Thompson, K.: Temporal and spatial variation in stocks of autotrophic and heterotrophic microbes in the upper water column of the central Arctic Ocean, Deep-Sea Res. Pt. I, 50, 557-571, 2003.

Smith Jr., W. O.: Primary Productivity of a Phaeocystis Bloom in the Greenland Sea During Spring, 1989, Geoph. Monog. Ser., 85, 263-272, 1994.
Smith Jr., W. O.: Primary productivity and new production in the Northeast Water (Greenland) Polynya during summer 1992, J. Geophys. Res., 100, 4357-4370, https://doi.org/10.1029/94JC02764, 1995.

Telling, J., Anesio, A. M., Hawkings, J., and Tranter, M.: Measuring rates of gross photosynthesis and net community production in cryoconite holes: a comparison of field methods, Ann. Glaciol., 51, 153-162, 2010.

Terrado, R., Lovejoy, C., Massana, R., and Vincent, W.: Microbial food web responses to light and nutrients beneath the coastal Arctic Ocean sea ice during the winter-spring transition, J. Marine Syst., 74, 964-977, 2008.

Vader, A., Marquardt, M., Meshram, A. R., and Gabrielsen, T. M.: Key Arctic phototrophs are widespread in the polar night, Pol. Biol., 38, 13-21, https://doi.org/10.1007/s00300-014-15702, 2015.

Vaquer-Sunyer, R., Duarte, C. M., Holding, J., Regaudie-deGioux, A., García-Corral, L. S., Reigstad, M., and Wassmann, P.: Seasonal patterns in Arctic planktonic metabolism (Fram Strait - Svalbard region), Biogeosciences, 10, 1451-1469, https://doi.org/10.5194/bg-10-1451-2013, 2013.

Vancoppenolle, M.. Bopp, L., Madec, G., Dunne, J., Ilyina, T., Halloran, P. R., and Steiner, N.: Future Arctic Ocean primary productivity from CMIP5 simulations: Uncertain outcome, but consistent mechanisms, Global Biogeochem. Cy., 27, 605-619, https://doi.org/10.1002/gbc.20055, 2013.

Wassmann P., Duarte, C. M., Agust, S., and Sejr, M. K.: Footprints of climate change in the Arctic marine ecosystem, Glob. Change Biol., 17, 1235-1249, https://doi.org/10.1111/j.13652486.2010.02311.x, 2011.

Wessel, P. and Smith, W. H. F.: A Global Self-consistent, Hierarchical, High-resolution Shoreline Database, J. Geophys. Res., 101, 8741-8743, 1996.

Zhang, Q., Gradinger, R., and Spindler, M.: Dark Survival of Marine Microalagae in the High Arctic (Greenland Sea), Polarforschung, 65, 111-116, 1998. 